\title{
Nermina Čordalija
}

\section{THE THEORY OF ASPECT AND ITS PROCESSING CORRELATES IN NEUROLINGUISTIC AND PSYCHOLINGUISTIC STUDIES}

Languages convey aspectual meanings differently. Generally, there are two types of aspect: lexical aspect and grammatical aspect. Lexical aspect relates to inherent features of the predicate, whilst grammatical aspect, sometimes dubbed as viewpoint aspect, expresses the speaker's viewpoint. Nevertheless, in traditional theoretical linguistics, these two aspectual systems are typically defined in terms of the same or similar criteria. The article discusses lexical and grammatical aspect in more detail and points out the problems that theoretical linguistics encounters when defining lexical and grammatical aspect in terms of the same holistic criterion. Importantly, the article outlines findings of psycholinguistic and neurolinguistic studies which (possibly to the dissatisfaction of theoretical linguistics) unambiguously show that lexical and grammatical aspect are indeed inextricably linked. Perfective and imperfective aspect do model the comprehender's understanding of the situation as complete (perfective aspect) or ongoing with all the stages, participants and locations cognitively more available to the comprehender (imperfective aspect).

Key words: lexical aspect, grammatical aspect, perfective, imperfective, progressive, perfect, general-factual imperfectives, imperfective paradox, situation models, ERP

\section{INTRODUCTION}

The expression of aspectual meanings is ubiquitous in natural languages (cf. Baggio, 2008). Aspect relates to time in its own unique way and cross-linguistically, reference to time is inherent to linguistic expressions. In the sentence, aspectual information is conveyed via lexical aspect and grammatical aspect. Lexical and grammatical aspect are both rooted in 
semantics - they express semantic concepts of telicity or boundedness. Nevertheless, in many languages, the latter is grammaticalized via inflectional, or in the case of Slavic, inflectional-derivational morphology (see Bybee, 1985). In this paper, I briefly describe both types of aspect. Then, I address the challenge of defining these two types of aspect which have been, despite them representing rather different systems, defined in the literature in terms of the same holistic criteria (whole vs. part). Finally, the paper provides a valuable insight into psycholinguistic and neurolinguistic studies that show how pragmatically relevant a neat theoretical separation of lexical and grammatical aspect is. Most examples in this paper are provided in English. However, when referring to perfective and imperfective aspect, the canonical exemplars of grammatical aspect, examples from Slavic languages are provided.

\section{LEXICAL ASPECT}

Different terminology is encountered in the literature on lexical aspect: Aktionsart (Platzack, 1979; Hinrichs, 1985; Krifka, 1989), aspectual class (Dowty, 1979; Verkuyl, 1993; 2005; de Swart, 2012), situation aspect/types (Smith, 1991; 1997; 2013), eventuality types (Bach, 1986; Filip, 1999), inner aspect (Verkuyl, 1993; 2005) and a more general term, lexical aspect (Rothstein, 2004; Filip, 2012 among many others). Lexical aspect is typically understood as an expression of the inherent features of the verb (terminative, resultative, iterative, augmentative etc.). However, Smith (1991; 1997; 2013) uses the term 'the verb constellation' to point out that lexical aspect is not merely a feature of the verb, but is rather computed compositionally from the verb and its arguments. Consider the following examples from Tenny (1994).

(1) John consumed an orange.

(2) John consumed oranges.

In (1) the theme object is delimited, so that the verb constellation expresses the situation type typically described as 'accomplishment', a process that goes on in time but has a set terminal point. In (2) 'oranges' is unlimited and thus the situation type is 'state' as states are all situation types that express a pattern rather than a discrete situation (Krifka et al., 1995). Generally, theme objects can indicate the span of verbal action. Such themes 
are called 'incremental themes' (Dowty, 1991) and can be found with situations such as 'draw a circle' or 'consume an orange'. Krifka $(1989 ; 1992)$ refers to these objects as 'gradual or successive patients'. The main idea is that the extent of the theme determines the extent of the situation. However, this need not be the case for all situation types - consider the verb constellation 'prove a theorem' (Rothstein, 2004; Smith, 2013).

Therefore, more generally, Ryle (1949), Kenny (1963), and Vendler (1957), among many others, defined several classes of verbs based on their lexical aspect. Vendler's classification (1957) assumes the existence of four classes of verbs: states, activities, achievements, and accomplishments. Similarly, Smith (2013) classifies situation types as states and events. Events can be accomplishments (recover from illness), achievements (reach the top), activities (sleep) and semelfactives (knock). In Smith (2013), the situation type of state includes generic meanings (Sam is happy) as well as habitual meanings (Lions eat meat). Essentially, what distinguishes these situation types are binary temporal features: stative - dynamic, telic-atelic, punctual-durative (Smith, 1991; 1997; 2013).

Dynamic situations consist of various stages and involve a change whereas stative situations express unbroken states of affairs and consist of an undifferentiated time interval (Smith, 1991; 1997; 2013). Dynamic situations can occur in English progressive aspect (is running), pseudo-cleft constructions (What he did was to run all day) and with adverbials of motion (He ran quickly) (Smith, 2013). In English simple present tense, dynamic situations have a habitual interpretation (He reads a book). Durative events span over an interval (to sleep) while punctual events unfold instantaneously (to reach the top) (Smith 1991; 1997; 2013). Atelic situations do not have an inherent end-point but an arbitrary one whilst telic situations have a natural endpoint and denote actions tending towards a goal (Garey, 1957; Smith 1991; 1997; 2013; Padučeva, 2009). Telic verb constellations can be used with in - adverbials (Mary drew a picture in three hours) whereas atelic verb constellations can be used with durative for - adverbial (Mary slept for an hour) (Vendler, 1957; Smith, 1991; 1997; 2013; de Swart, 1998; Ramchand, 2008; Kennedy, 2012).

The telic - atelic contrast in situations leads to a very different relationship between the progressive and the non-progressive (Vendler, 1957). 
Telic situations are heterogenous - they involve a change once the terminal point is reached which means that there is no semantic entailment from the progressive to the non-progressive (Mary was drawing a circle does not entail Mary drew a circle) (Vendler 1957; Smith 1991; 1997; 2013). Atelic situations are homogenous and do involve the progressive - non-progressive semantic entailment (Mary was sleeping entails Mary slept) (Vendler 1957; Smith 1991; 1997; 2013).

In summary, verb constellations have their basic interpretations that rest on the above-mentioned criteria. Smith (1999) offers the following summary of the basic meanings of verb constellations based on their lexical aspect:

- states are stative and durative $(k n o w, b e)^{1}$

- activities are dynamic, durative and atelic (sleep, push a cart)

- accomplishments are dynamic, durative and telic (draw a picture)

- achievements are dynamic, punctual and telic (reach the top)

- semelfactives are dynamic, punctual and atelic (flap a wing)

Bach (1981; 1986), Verkuyl (1993) and de Swart (1998) use somewhat different terminology. They classify situations into states, processes (activities) and events (achievements and accomplishments). However, in their frameworks too, the binary features telic/atelic, durative/punctual, stative/ dynamic are the basic criterion for the description of situation types.

We can proceed with caution and generally assume that telic events are bounded and that atelic events are unbounded (see Borik, 2006 for the criticism of this generalization). Nevertheless, boundedness information (the attainment of the final boundary of the event) is primarily conveyed by grammatical aspect (Krifka, 1989; 1992; Smith, 2013)

\section{GRAMMATICAL ASPECT}

Some languages express the category of aspect morphologically, either synthetically (e.g., Bosnian/Croatian/Serbian) or analytically (e.g., English). Slavic perfective and imperfective aspects are regarded as the prototypical exponents of the grammatical aspect category. Traditionally, perfective grammatical aspect is described as conveying bounded situations

\footnotetext{
${ }^{1}$ According to Smith (1999), the concept of state does not include endpoints.
} 
and looking at the situation as a whole, from the outside without recognizing different phases that make up the situation (Comrie, 1976; Smith, 1991; 1997; 2013; Filip, 1999; Madden and Zwaan, 2003) as in (3). Imperfective grammatical aspect expresses an internal view of the situation and makes semantically visible the stages of the situation (Comrie, 1976; Smith, 1991; 1997; 2013; Filip, 1999; Madden and Zwaan, 2003) without specifying its endpoints (Smith, 1991; 1997; 2013) as in (4).

(3) Učenica je napisala zadaću.

Student aux PRS $_{\text {Prote }}$ PTCP.PFV homework

'The student wrote her homework.'

(4) Učenica je pisala zadaću.

Student aux Prote $_{\text {PTCP.IPFV }}$ homework

'The student was writing her homework.'

Therefore, grammatical aspect has been traditionally analyzed in terms of the part-whole relationship (Smith 1991; 1997; 2013; Filip, 1999). Bach (1986), for example, argues that the progressive operator (the English equivalent of the imperfective) in the verbal domain is equivalent to the partitive operator in the noun phrase. Essentially, the dimension of lexical aspect that assumes the existence of inherently telic and atelic situations and grammatical aspect are hence both defined in terms of the same holistic criterion. Such tradition in theory can give rise to paradoxical situations in language from the point of view of linguistic theory. One such situation is perfectly illustrated by the imperfective paradox (the imperfective puzzle in Bach, 1986).

The imperfective paradox occurs when a normally telic situation with an inherent endpoint occurs in the imperfective that does not signal completion according to classical definitions. The imperfective paradox, thus, presents a conflict between the inherent situation type and its outcome in a given context (Dowty, 1979). Consider the following example.

(5) They were building a house.

The situation type in (5) is an accomplishment that is inherently telic (having an inherent endpoint). However, the progressive aspect (as a type of imperfective) in (5) presents such telic situation from the internal point of view as consisting of stages and ongoing with no information about its 
completion. Nevertheless, in the world around us, we would expect such a situation to reach its final point eventually despite the progressive (imperfective) marking on the verb.

Another challenge to classical definitions of grammatical aspect occurs in the form of the so-called 'fake' or 'general-factual' imperfectives (Dickey, 2000; Grønn, 2004; Alvestad, 2014; Mueller-Reichau, 2018). Indeed, thoroughly studied and debated are the uses of the imperfective to present complete and bounded events which are regularly found in Slavic languages especially in East Slavic languages. This use of the imperfective is available in Bosnian/Croatian/Serbian too.

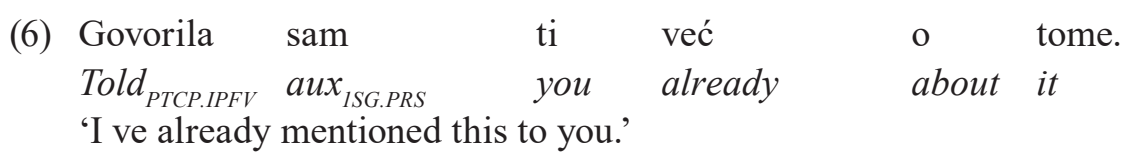

The imperfective aspect in (6) presents a complete and bounded situation and not an internal interval as a part of the overall situation that is a typical imperfective interpretation. Gasparov (1990) argues that such general-factual uses of the imperfective imply an existential interpretation (that a certain event occurred).

Grønn (2004) describes the uses of the imperfective for single completed events as existential or presuppositional. The example in (6) is a case of an existential imperfective where the occurrence of the event is stated with time and duration of the event not being relevant. In presuppositional imperfectives, the first occurrence of the bounded situation is presented by a perfective verb, however, the second time the situation is mentioned, the imperfective may be used (Grønn, 2004; Alvestad, 2014) as in the example below:

(7) Izvrnite džepove! Izvrćite kad vam kažem. Empty $_{2 P L . P F V}$ pockets! Empty ${ }_{2 P L . I P F V}$ when you tell ISG.PRS $_{\text {. }}$ 'Empty you pockets! Empty them immediately!'

Alvestad (2014) shows that both types of bounded and non-durative meanings of the imperfective occur in the imperative too as illustrated in (7). She conducted a corpus study using a ParaSol corpus and the novel How the Steel was tempered by Ostrovskij (1926) which showed that the expectation that the perfective should be dominant in the imperative sentences 
as the imperative is used to instigate a change, is not borne out. Her results show that in imperative sentences, West Slavic languages use the imperfective in $30 \%$ and East Slavic in $60 \%$ of cases. She argues that in such cases, aspectual competition arises as both aspects can be used without any significant change in meaning. Slavic languages differ in how they resolve this aspectual competition. For example, the distribution of general-factual imperfectives in Bosnian/Croatian/Serbian patterns more with the West Slavic group (Mueller-Reichau, 2018).

Crucially, traditional depictions of grammatical aspect cannot account for the general-factual uses of the imperfective and give rise to the imperfective paradox. One of the reasons for this is that two very different aspectual systems, lexical and grammatical aspect, are defined in terms of the same part-whole, complete-incomplete binary oppositions (Borik, 2006) even though there is a general consensus in the literature that they embody two different aspectual systems (Dahl, 1985; Depraetere, 1995; Dowty, 1979; Filip, 1999; Klein, 1994; Smith 1991; 1997; 2013 among many others).

\section{THE SEPARATION OF LEXICAL AND GRAMMATICAL ASPECT IN THEORY}

Borik (2006) argues for a theoretical separation of two aspectual domains - lexical aspect and grammatical aspect, two essentially different aspectual systems. They are different because lexical aspect concerns the situation itself and its inherent properties and grammatical aspect expresses the speaker's perspective on the situation (Borik, 2006).

Expectedly, this idea is not without precedent. Comrie (1976), Depraetere (1995), Klein (1994; 1995), Filip (1999), Smith (1991; 1997; 2013) recognize that lexical aspect and grammatical aspect are different systems. Nevertheless, Filip (1999) claims that all aspectual systems can be described in terms of the part-whole relation which entails that the definitions of two different aspectual systems are grounded in same semantic concepts and thus the formal implementation of the difference between the two aspectual systems is not stated (Borik, 2006). According to Klein (1994; 1995) the criterion that assumes that perfective aspect gives a holistic view of the situation and imperfective aspect offers a view of the part of the situation 
does not entail a concrete semantic property of different aspects. It rather captures native speakers' intuition regarding (im)perfectivity. Klein further points out that if the perfective possesses the holistic feature, it is not clear whether the imperfective should have a negative holistic feature or an unspecified one. The theory that relies on the part-whole relation encounters insurmountable obstacles when accounting for examples such as (7) above where despite the imperfective feature on the verb, the situation is presented in its totality.

Smith (1997) offers the account of the imperfective which posits two uses for the imperfective aspect: the basic use for progressive situations and the so-called conventional use (the general-factual use) where the meaning of progress and unboundedness, typically expressed by the imperfective, is absent. These conventional uses of the imperfective are constrained by pragmatics according to Smith (1997) and Filip (1993, 1999). However, this theory does not provide any tools in predicting the distribution of the basic or the conventional use. Borik (2006) points out that Smith's (1997) account of the imperfective leaves unclear what is the common property behind all imperfectives as well as the question why the conventional imperfective overrides the use of the holistic perfective in examples such as (6-7) above where intrinsically holistic situations are presented.

Klein (1995) further exemplifies the inadequacy of conventional definitions of perfective and imperfective aspect.

$\begin{array}{llllll}\text { (8) Prošluju noč } & \text { Ivan spal v komnate } & \text { dlja } & \text { gostej. } \\ \text { Last } & \text { night } & \text { Ivan } & \text { slept }_{\text {IPFV }} \text { in room } & \text { for } & \text { guests. }\end{array}$ 'Last night, Ivan slept in the guest room.'

According to Klein (1995), the example in (8) shows that the verb carries the imperfective feature but that there is no reason to assume that an event is not presented in its totality and that the external boundaries cannot be interpreted.

Klein (1995) further shows that the approach to aspect that relies on (non-) attainment of the absolute boundary of the event is empirically not supported.

$\begin{array}{lllll}\text { (9) Včera } & \text { Severin } & \text { rabotala } & \text { s } & \text { dvuch do pjati. } \\ \text { Yesterday } & \text { Severin } & \text { work }_{I P F V} & \text { from two to five. }\end{array}$


'Yesterday Severin worked from two to five.'

In (9) the beginning and the end of the verbal action are clearly indicated by time adverbials thus, a past event with a limited duration and clear boundaries is presented by an imperfective verb.

Therefore, one of the major issues with using the part-whole criterion in defining grammatical aspect is that it is easily merged with inherent lexical aspect and that it raises the question whether it is the perfective that is marked for completeness and the imperfective is either marked for incompleteness or unmarked altogether. To tackle these challenges in defining grammatical aspect and formally separate definitions for two different aspectual systems, lexical and grammatical, Klein (1995), offers a time-relational analysis of grammatical aspect. He introduces the terms time of utterance, time of situation and time of assertion which are similar to terms introduced by Reichenbach (1947).

Klein (1995) defines tense as a time relation between the time of utterance and the time of assertion. In (10), the time of assertion precedes the time of utterance and thus the verb expresses the past tense. The time of situation and the time of assertion can coincide as they do in (11) but this is not always the case as (12) shows.

(10) It was raining.

(11) It is raining.

(12) John has closed the window.

The example in (12) shows that the utterance time and the time of assertion overlap, while the time of situation precedes them. Klein (1995) argues that this very relation between the time of situation and the time of assertion is conveyed by aspect.

Klein (1995) assumes that in English perfect, the assertion time follows the time of the event as (12) shows. The progressive, on the other hand, implies that the assertion time is a subinterval of the situation time. The simple past form marks that the assertion time and the situation time overlap as in (13).

(13) John closed the window.

Klein (1995) claims that there is a parallelism in the perfective/imperfective relation in Slavic and simple/perfect/progressive relation in English 
but no complete identity. In his theoretical framework, in the perfective aspect, the target state of the verb is reached within the assertion time while this is not true for the imperfective. The imperfective places the assertion time in the middle of the event and makes no assumptions whether the target state is reached. However, often the implication is that the target state is reached. In the case of the general-factual reading of the imperfective that is used for completed actions in the past as in (6-7), he believes that the assertion time includes the time of situation. However, in the case of the progressive meaning, the assertion time is a subinterval of the time of situation. Which meaning of the imperfective is intended depends on the pragmatic factors. Therefore, Klein (1995) explains that in examples such as (11) where the general-factual imperfective is used for what is a clearly bounded event, the assertion time includes the situation time and that is why the progressive reading is not intended and the sentence expresses the existence of the event without the assertion time representing a subinterval of the time of the situation.

$\begin{array}{llll}\text { (14) Vy čitali } & \text { Vojnu } & \text { i } & \text { mir? } \\ \text { You read } & \text { War } & \text { and } & \text { Peace? } \\ \text { 'Have you read War } & \text { and Peace?' } & & \end{array}$

Borik (2006) too argues against the definition of grammatical aspect in terms of traditional notions. She models a theory of Russian aspect following Reichenbach's (1947) model of three time points (time of speech, time of event, time of reference). Similarly to Klein (1995), she argues that aspect is determined by the relation between the reference time (assertion time in Klein, 1995) and the event time (situation time in Klein, 1995). Klein (1995) and Borik (2006) formally capture the intuition that lexical and grammatical aspect are different aspectual systems and define them in fundamentally different ways. Grammatical aspect expresses the relation between the event time and the reference that is made for that event, while lexical aspect is defined in terms binary features telic/atelic, durative/punctual, stative/dynamic. 


\section{AN INTERIM COMPARISON OF BOSNIAN/ CROATIAN/SERBIAN AND ENGLISH ASPECT}

The aspect systems of these languages show different aspectual realizations. The Bosnian/Croatian/Serbian aspectual system distinguishes between the perfective and the imperfective as in (3-4) above. Descriptive grammars in English specify aspectual distinctions between the progressive and the perfect (Comrie, 1976; Greenbaum and Quirk, 1990; Jacobs, 1995; Biber et al., 1999; Greenbaum and Nelson, 2009; Hasselgård et al., 2011). The status of the English perfect aspect has been a matter of debate and it is worth noting that some authors consider the perfect a temporal operator rather than an aspectual operator (Huddleston and Pullum, 2002; Leech, 2004). Unlike the Bosnian/Croatian/Serbian aspectual system that uses complex aspectual morphology (prefixes and suffixes) on the verb, the English progressive and perfect aspects are expressed periphrastically in an auxiliary + participle construction (Quirk et al., 1985; Jacobs, 1995; Aarts, 2001; Greenbaum and Nelson, 2009; Filip, 2011; Hasselgård et al., 2011) as (15-16) show. Tense is marked on the operator as either past or present as in (15-16).

(15) The student was writing homework. (Progressive)

(16) The student has written her homework. (Perfect)

In addition to different formal realizations of aspect, the relationship between the aspectual form and its aspectual meaning is not identical in both languages. Parsons (1998) posits that progressive aspect expresses that a certain state continues and the non-progressive that a certain event culminates. Ter Meulen (1985), Link (1987) and Krifka (1992) base their analyses on the idea that the progressive describes a segment of the event. Similarly, Vlach (1981) and Lascarides (1991) argue that the progressive entails a process that is ongoing at the time expressed by tense information. Therefore, the English progressive aspect corresponds to Bosnian/ Croatian/Serbian imperfective for the most part.

Habitual meanings conveyed by the imperfective in Bosnian/Croatian/ Serbian are expressed by simple forms in English. English does not possess a grammaticalized perfective aspect but perfective meanings can be expressed by the perfect aspect as in (16) above or by formally aspectless simple forms as in (17). 
(17) The girl wrote her homework.

In summary, English expresses the imperfective aspectual meaning by the progressive whilst perfect aspect and aspectually unmarked simple forms typically express perfective meanings. This statement is immensely important as most studies presented in the following section focused on English aspect.

\section{A PSYCHOLINGUISTIC AND NEUROLINGUISTIC PERSPECTIVE ON LEXICAL AND GRAMMATICAL ASPECT}

Several authors conducted experiments to observe how grammatical aspect distinctions affect situation models. 'Situations models' is a term that refers to the building of mental representation of the situation expressed by the sentence (Zwaan and Radvansky, 1998). The process of creating mental representations relies on the interaction syntax, semantics and pragmatics. Remember that Klein (1995) and Borik (2006) argue against the view of grammatical aspect as conveying complete or durative situations because this is the definition of lexical aspect, more precisely - telicity.

In three experiments that involved reading passages and responding to subsequent questions, Carreiras, Carriedo, Alonso and Fernandez (1997) found that characters in short narratives are more easily activated in memory when their actions had been described in the past progressive (the equivalent of the imperfective) rather than past perfect (the equivalent of the perfective).

In an experiment where participants read passages and were asked questions about the ongoingness or completion of events, Magliano and Schleich (2000) found that readers interpret imperfective events as ongoing and perfective events as completed and that ongoing events decay at a slower rate than completed events.

Madden and Zwaan (2003) conducted three experiments in English where verbs occurred in either the past progressive expressing ongoing events (the imperfective meaning) or the past simple expressing completion (the perfective meaning). Their two sentence-picture matching experiments 
showed that participants were more likely to choose and were faster to respond to pictures showing completion rather than ongoingness having heard the verb in the past simple form. They did not show preference or difference in reaction latencies for ongoing pictures or completed pictures after hearing the verb in the past progressive. In the third experiment, participants were faster to read the past simple sentences after seeing a picture expressing a completed event but they showed no difference in reading the past progressive sentences after seeing a completed or ongoing picture. They explain that when perfective aspect (English past simple in this case) is used to describe an event, speakers build mental representations of completed events. When imperfective aspect (English past progressive in this case) is used to express an event, speakers build mental representations of events in different stages of completion.

Anderson, Matlock, Fausey and Spivey (2008) presented participants with English sentences with verbs in the past simple or the past and participants were instructed to drag and drop characters to an appropriate place on the path (Tom jogged/was jogging to the woods and then stretched when he got there). Participants showed a tendency to put the characters in the beginning or the middle of the path after hearing a sentence with the imperfective verb, whereas, they typically put characters at the end of the path after hearing the sentence with the verb in the past simple.

Madden and Therriault (2009) conducted another experiment on the interaction between verbal aspect and situation representations. The simulation view of language comprehension assumes that words activate general word meanings which represent lexical-level simulations, which, when combined, produce situation-specific simulations of phrases and sentences which rely on reactivations of our previous experience (Barsalou, 1999; Madden and Therriault, 2009). Madden and Therriault (2009) give the following example: if we read about walking in the rain, we simulate the experience of walking in the rain and everything associated with it including the instruments such as an umbrella. However, they claim such simulations are more likely to include the pictures of objects in use, an open umbrella as opposed to the closed umbrella and they refer to this as 'the use effect'. They start from the assumption that initial simulations of participants in a certain situation are not dependent on grammatical cues, thus in the situation described above - walking in the rain - we build a simulation of an 
open umbrella, the object in use, regardless of, say, aspectual cues, whether the situation is completed or not. However, the time course of the use effect is what they focus on, and their question is if aspectual features interact with the use effect, in the sense that the use effect would be expected to dissipate in case of perfective sentences and to continue in case of imperfective sentences. Remember that all the experiments described above showed that the imperfective gives access to all stages of a situation whilst the perfective does not, it rather focuses on the resultant stage.

Madden and Therriault (2009), therefore, designed a self-paced reading experiment with pictures of objects in use or not in use (open vs. closed umbrella) that followed the main verb to observe if and how verbal aspect constrains simulations. In addition to the online task - button presses, every sentence was followed by an offline task - an acceptability judgment. They used past perfect to express perfective aspect in English (completion) and past progressive to express imperfective/progressive aspect (progress, no information of completion). Both online and offline data (RTs for button presses and acceptability judgments - accuracy and RT) showed that in perfect sentences (had used the umbrella), the use effect (pictures of objects in use being integrated more easily which occurs as facilitation in RTs) occurred only on the picture. On two subsequent words, the use effect was not statistically significant. In the progressive sentences (was using the umbrella), the use effect was statistically significant in all critical positions - on the image, two subsequent words and the acceptability question. They conclude that ongoing simulation (object in use) is initially activated but as soon as it is integrated in the structure in perfect(ive) sentences, it is quickly deactivated because the simulation of the ongoing situation is not compatible with perfect(ive) aspectual features of the preceding verb that denotes completion. In the case of progressive sentences, aspectual features of the verb are compatible with the simulation of an ongoing situation (object in use) which facilitates reaction times on two subsequent words as well as acceptability judgments. They conclude that aspectual information regulates the time-course of the activation of ongoing simulations.

Matlock (2011) showed that when participants are asked to complete sentences with a preceding subordinate clause either in the past simple (When John walked to school) or the past progressive (When John was walking to school), they could name more actions when the previous clause contained 
the past progressive. Similarly, in Matlock (2010), participants read sentences in the past simple (Bob planted pine trees along his driveway last week) indicating completion and the past progressive expressing duration (Bob was planting pine trees along his driveway last week) and were asked to estimate the length of the path. The experiment showed that estimates tended to be larger in sentences with the past progressive. This indicates that participants construe events differently depending on the aspectual distinctions.

Ferretti, Kutas and McRae (2007) conducted an event-related potentials (ERP) experiment in which participants were given verbs in the past progressive and the past perfect in English and associated locations where the events are very likely to take place (The diver was snorkelling in the ocean) or less likely to take place (The diver was snorkelling in the pond). Generally, ERP experiments measure electrical potentials of the brain from the onset of the event (i.e., the stimulus). Their results showed that the N400 amplitudes (the ERP component reflecting that electrical potentials of the brain generate higher amplitude in case of semantic anomalies) varied as a function of verbal aspect. Participants had the least difficulty integrating locations in sentences with past progressive verbs when the locations were typical for those events. Conversely, participants had the most difficulty integrating locations following the same verbs in the past progressive when the locations were plausible but not common for the events which was reflected in large N400s. The N400 amplitude to the locations following the same events expressed in sentences with past perfect aspect were intermediate and did not vary significantly depending on whether the location was common of the event or not. They explain that this occurred because participants form expectations with regards to location of the event when sentences are presented in the progressive form. However, when they occur in the past perfect, expectations are less formed because they are less expected as the perfect presents the situation in its totality without access to its stages and participants or location. They hence argue that imperfective aspect makes the whole event available with all its stages, while perfect(ive) aspect focuses on the resultant state. 


\section{CONCLUSION}

In previous sections, it was argued that whilst grammatical aspect expresses a speaker's perspective on the internal temporal constituency of the event, lexical aspect relates to the inherent features of the predicate computed compositionally from the meaning of the verb and its arguments (John ate an apple = telic; John ate apples = atelic). However, I pointed out that despite this obvious fact that they represent rather different aspectual systems, traditional depictions of grammatical aspect and lexical aspect rely on the similar holistic criterion. Moreover, I outlined the challenges that such traditional definitions that confound grammatical and lexical aspect face, one of them being the use of the imperfective to present complete and bounded events which regularly occur in Slavic. For that reason, the paper provided an overview of proposals by Klein (1995) and Borik (2006) that call for a formal separation of lexical and grammatical aspectual systems. More precisely, in those frameworks, lexical aspect was defined in terms of binary features telic/atelic, durative/punctual, stative/dynamic whilst grammatical aspect was defined as an expression of the relation between event time and reference time. Therefore, it seems that at the heart of the problem in defining lexical and grammatical aspect is using the partwhole criterion to define grammatical aspect.

For that reason, to probe into the processing correlates of grammatical aspect, the paper outlined the findings from psycholinguistic and neurolinguistic studies. More specifically, I presented the studies by Carreiras, Carriedo, Alonso and Fernandez (1997), Magliano and Schleich (2000), Madden and Zwaan (2003), Ferretti, Kutas and McRae (2007), Anderson, Matlock, Fausey and Spivey (2008), Madden and Therriault (2009) and Matlock (2011). All previously mentioned studies suggest that imperfective aspect gives the inside view of the event and makes its stages, participants and locations available to the comprehender, whilst perfective aspect expressed by perfect or simple forms in English gives the outside view and focuses on the resultant stage. What this entails is that construing events expressed by predicates formally marked for grammatical aspect actually does rely on the holistic and non-holistic mental representation of events. Perfective aspect shapes our understanding of events as bounded wholes whilst imperfective aspect, cognitively speaking, gives a progressive and durative dimension to events. These findings, then, suggest that Klein's 
(1995) and Borik's (2006) neat theoretical separation of lexical and grammatical aspect is useful in theoretical linguistics because it can rather comprehensively account for examples such as general-factual imperfectives, for example. However, in actual language use, telicity (lexical aspect) and grammatical aspect (perfective and imperfective) are so inextricably linked that speakers inevitably understand imperfective aspect as presenting ongoing situations with different stages whilst perfective aspect puts more emphasis on the result and completion of the event. Mind you that incredibly similar criteria are used to define telicity - telic events have an inherent end-point, atelic events do not and imply progress and duration.

Experimental studies, therefore, show that teasing lexical and grammatical aspect apart might prove to be a (methodologically) complex endeavour. More concretely, the studies presented in Section 6 suggested that these two systems cannot be neatly teased apart in terms of how they cognitively shape our understanding of events in the sentence because they do so through an incredibly close interaction. Admittedly, to my knowledge, no experimental studies tackled the exceptional cases that show incongruence between actual boundedness of the event and the aspectual feature on the verb (e.g., general-factual imperfectives, bounded events expressed by the imperfective). Hence, it might be worthwhile to investigate more closely the non-prototypical uses of imperfective and perfective aspectual oppositions for a better understanding of the interaction between lexical and grammatical aspect and the need for a formal separation of the two in theory.

\section{REFERENCES}

Aarts, B., 2001. English syntax and argumentation. New York: Palgrave.

Alvestad, S.S., 2014. "Fake imperfective imperatives in Slavic". In: Ebeling, S. O.,Grønn, A., Hauge, K. R., Santos, D. eds. Corpus-based studies in contrastive linguistics. Oslo: Oslo Studies in Language, pp. 29-42.

Anderson, S. E., Matlock, T., Spivey, M., 2013. "Grammatical aspect and temporal distance in motion descriptions". Frontiers in Psychology, 4, Article 337.

Bach, E., 1981. "On time, tense and aspect: An essay in English metaphysics". In: Cole, P. ed. Radical Pragmatics. New York: Academic Press, pp. 63-81. 
Bach, E., 1986. "The algebra of events". Linguistics and Philosophy, 9(1), pp. $5-16$.

Baggio, G., 2008. "Processing temporal constraints: An ERP study". Language and Learning, 58(1), pp. 35-55.

Barsalou, L.W., 1999. "Perceptual symbol systems". Behavioral and Brain Sciences, 22, pp. 577-660.

Biber, D. et al., 1999. Longman grammar of spoken and written English. Pearson Education Ltd.

Borik, O., 2006. Aspect and reference time. Oxford: Oxford University Press.

Bott, O., Gattnar, A., 2015. "The cross-linguistic processing of aspect - An eyetracking study on the time course of aspectual interpretation in Russian and German". Language, Cognition and Neuroscience, 30(7), pp. 877-898.

Bybee, J. L., 1985. Morphology: A study of the relation between meaning and form. Amsterdam: John Benjamins.

Carreiras, M. et al., 1997. "The role of verb tense and verb aspect in the foregrounding of information during reading”. Memory and Cognition, 25(4), pp. 438-446.

Comrie, B., 1976. Aspect. Cambridge: Cambridge University Press.

Dahl, Ö., 1985. Tense and aspect systems. Oxford and New York: Basil Blackwell Inc.

Depraetere, I., 1995. "On the necessity of distinguishing between (un)boundedness and (a)telicity". Linguistics and Philosophy, 18, pp. 1-19.

De Swart, H., 1998. "Aspect shift and coercion". Natural Language and Linguistic Theory, 16(2), pp. 347-85.

De Swart, H., 2012. "Verbal Aspect". In: Binnick. R. ed. The Oxford handbook of tense and aspect. Oxford: Oxford University Press, pp. 752-781.

Dickey, S., 2000. Parameters of Slavic aspect. Stanford: CSLI.

Dowty, D. R., 1979. Word meaning and Montague grammar. The semantics of verbs and times in generative semantics and in Montague's PTQ. Dordrecht: Reidel.

Dowty, D. R., 1991. "Thematic proto-roles and argument selection". Language, 67(3), pp. 547-619.

Ferretti, T. R., Kutas, M., McRae, K., 2007. "Verb aspect and the activation of event Knowledge”. Journal of Experimental Psychology, 33(1), pp. 182-196.

Filip, H. 1999. Aspect, eventuality types and noun phrase semantics. New York and London: Garland Publishing. 
Filip, H., 2011. "Perfect and progressive". In: Heusinger, K, Maieborn, C., Portner, P. eds. Semantics. Berlin: De Gruyter Mouton, pp. 1217-1261.

Filip, H., 2012. "Lexical aspect". In: Binnick, R. ed. The Oxford handbook of tense and aspect. Oxford: Oxford University Press, pp. 721-752.

Garey, H. B., 1957. "Verbal aspect in French". Language, 33(2), pp. 91-110.

Gasparov, B., 1990. "Notes on the 'Metaphysics' of Russian aspect". In: Thelin, N. B. ed. Verbal aspect in discourse: Contributions to the semantics of time and temporal perspective in Slavic and non-Slavic languages. Amsterdam: John Benjamins, pp. 191-212.

Greenbaum, S., Quirk,.R., 1990. A student's grammar of the English language. Longman.

Greenbaum, S., Nelson, G., 2009. An introduction to English grammar. London and New York: Routledge.

Grønn, A., 2004. The semantics and pragmatics of the Russian factual imperfective. Ph. D. University of Oslo.

Hasselgård, H., Lysvåg, P., Johansson, S., 2011. English grammar: Theory and use. Oslo: Universitetsforlaget.

Hinrichs, E., 1985. A compositional semantics for Aktionsarten and NP reference in English. Ph. D. Ohio State University.

Huddleston, R., Pullum, G.K., 2002. The Cambridge grammar of the English language. Cambridge: Cambridge University Press.

Jacobs, R. A., 1995. English syntax: A grammar for English language professionals. Oxford: Oxford University Press.

Kennedy, C., 2012. The composition of incremental change. In: Demonte, V., McNally, L. eds. Telicity, change, and state: A cross-categorial view of event structure. Oxford: Oxford University Press, pp. 103-120.

Kenny, A., 1963. Action, emotion and will. London and New York: Routledge.

Klein, W., 1994. Time in language. London and New York: Routledge.

Klein, W., 1995. “A time-relational analysis of Russian aspect”. Language, 71(4), pp. 669-695.

Krifka, M., 1989. "Nominal reference, temporal constitution and quantification in event Semantics”. In: Bartsch, R., Van Benthem, J., Van Emde Boas, P. eds. Semantics and contextual expression. Berlin: De Gruyter Mouton, pp. $75-117$.

Krifka, M., 1992. "Thematic relations as links between nominal reference and temporal Constitution". In: Sag, I., Szabolcsi, A. eds. Lexical Matters. Stanford: CSLI Publications, pp. 29-53. 
Krifka, M. et al., 1995. "Genericity: An introduction“. In: Carlson, G., Pelletier, F. J. eds. The generic book. Chicago: The University of Chicago Press, pp. $1-124$.

Lascarides, A., 1991. "The progressive and the imperfective paradox". Synthese, 87, pp. 401-447.

Leech, G. N., 2004. Meaning and the English verb. London and New York: Routledge.

Link, G., 1987. "Algebraic semantics of event structures". In: Groenendijk, J., Stokhof, J. M., Veltman, F. eds. Proceedings of the Sixth Amsterdam Colloquium. Amsterdam: Institute for Logic, Language and Computation, pp. 243-262.

Madden, C. J., Zwaan, R. A., 2003. How does verb aspect constrain event representations. Memory and Cognition, 31(5), pp. 663-672.

Madden, C. J., Therriault, D. J., 2009. "Verb aspect and perceptual stimulations". The Quarterly Journal of Experimental Psychology, 62(7), pp. 1294-1303.

Magliano, J. P., Schleich, M. C., 2000. "Verb aspect and situation models". Discourse Processes, 29, pp. 83-112.

Matlock, T., 2010. "Abstract motion is no longer abstract". Lang. Cogn. 2, pp. 243-260.

Matlock, T., 2011. "The conceptual motivation of aspect". In: Radden, G., Koch, P., Panther, K. eds. Motivation and the lexicon: Cognitive, communicative, perceptual and socio-cultural factors. Amsterdam: John Benjamins, pp. $133-147$.

Mueller-Reichau, O., 2018. "General-factual perfectives: On an asymmetry in aspect choice between western and eastern Slavic languages". In: Lenertova, D., Meyer, R., Šimik, R., Szucsich, L. eds. Advances in formal Slavic linguistics. Berlin: Language Science Press, pp. 289-31.

Padučeva, E. V., 2009. "Telicity and incremental theme". Russian Linguistics, 33, pp. 109-119.

Parsons, P., 1998. “The progressive in modal semantics”. Language, 74(4), pp. 760-787.

Platzack, C., 1979. The semantic interpretation of aspect and Aktionsarten. A study of the internal time reference in Swedish. Dordrecht: Foris Publications.

Quirk, R., Greenbaum, S., Leech, G., Svartvik, J., 1985. A comprehensive grammar of the English language. London: Longman.

Ramchand, G. C., 2008. Verb meaning and the lexicon: A first-phase syntax. Cambridge: Cambridge University Press. 
Reichenbach, H., 1947. Elements of symbolic logic. New York: Macmillan and Co.

Rothstein, S., 2004. Structuring events: A study in the semantics of lexical aspect. Oxford: Blackwell Publishing.

Ryle, G., 1949. The concept of mind. New York: Barnes and Noble.

Smith, C. S., 1991. The parameter of aspect. Dordrecht: Kluwer Academic Publishers.

Smith, C. S., 1997. The parameter of aspect. Dordrecht: Kluwer Academic Publishers.

Smith, C. S., 1999. "Activities: States or events". Linguistics and Philosophy, 22(5), pp. 479-508.

Smith, C. S., 2013. "Tense and aspect: Time across languages". In: Maienborn, C., von Heusinger, L., Portner, P. eds. Semantics: An international handbook of natural language meaning. Berlin: De Gruyter Mouton, pp. 2581-2608.

Tenny, L. C., 1994. Aspectual roles and the syntax-semantics interface. Dordrecht: Springer.

Ter Meulen, A., 1985. "Progressives without possible worlds". In: Eilfort, W. H., Kroeber, P. D., Peterson, K. L. eds. Papers from the regional meeting of the Chicago Linguistic Society. Chicago: Chicago Linguistic Society, pp. 408-423.

Vendler, Z., 1957. "Verbs and times". Philosophical Review, 66(2), pp. 143-160.

Verkuyl, H. J., 1993. A theory of aspectuality: The interaction between temporal and atemporal structure. Cambridge: Cambridge University Press.

Verkuyl, H. J., 2005. "Aspectual composition: Surveying the ingredients". In: Verkuyl, H. J., De Swart, H., Van Hout, A. eds. Perspectives on aspect. Dordrecht: Springer, pp. 1941.

Vlach, F., 1981. "The semantics of the progressive". In: Tedeschi, P., Zaenen, A. eds. Syntax and semantics 14: Tense and aspect. New York: Academic Press, pp. 271-292.

Zwaan, R., Radvansky, G. A., 1998. "Situation models in language comprehension and memory". Psychological Bulletin, 123, pp. 162-185. 


\title{
TEORIJA GLAGOLSKOG VIDA I NEUROLINGVISTIČKA I PSIHOLINGVISTIČKA SAZNANJA O NAČINU PROCESIRANJA GLAGOLSKOG VIDA
}

\begin{abstract}
Sažetak
Glagolski vid, odnosno aspekt, izražava se na različite načine u svjetskim jezicima. Obično se govori o dvije vrste glagolskog vida: leksički i gramatički. Leksički glagolski vid se izražava kroz osnovno značenje predikata, dok gramatički glagolski vid, koji se u literaturi također naziva i aspekt gledišta, izražava stav govornika prema glagolskoj radnji. Međutim, u tradicionalnoj teorijskoj lingvistici ova dva aspektualna sistema su obično definisana koristeći iste ili slične kriterije. Ovaj članak detaljnije analizira leksički i gramatički glagolski vid te ukazuje na probleme s kojima se teorijska lingvistika susreće prilikom definisanja leksičkog i gramatičkog aspekta koristeći isti holistički kriterij. Međutim, važno je istaći da članak također diskutuje nekoliko psiholingvističkih i neurolingvističkih studija koje (moguće na nezadovoljstvo teorijske lingvistike) nedvosmisleno pokazuju da su leksički i gramatički gramatički vid zaista neraskidivo povezani. Svršeni i nesvršeni glagolski vid drugačije oblikuju razumijevanje situacije: radnja se shvata kao cjelovita kada je izražena svršenim glagolskim vidom. Kada je izražena nesvršenim glagolskim vidom, radnja traje, te sve faze od kojih se glagolska radnja sastoji, učesnici radnje i lokacije povezane s radnjom kognitivno su dostupniji u poređenju s radnjom izraženom svršenim glagolskim vidom.
\end{abstract}

Ključne riječi: leksički glagolski vid, gramatički glagolski vid, svršeni glagolski vid, nesvršeni vid, engleski progressive, engleski perfect, nesvršena konstatacija činjenica, paradoks nesvršenog glagolskog vida, situacijski model, ERP 